\title{
The Cause of Speaking Anxiety of Pre- intermediate EFL Learners and Its Effects on Their Oral Performance
}

\author{
Sarah Al-Mukdad \\ Arab International University (AIU), Damascus, Syria
}

\begin{abstract}
This study is in the area of teaching English as a foreign language (TEFL). It focuses on the factors causing speaking anxiety to pre-intermediate EFL learners, the direct or indirect effects of speaking anxiety on the overall oral performance, in addition to suggesting possible treatments to this problem. The study was conducted at The Higher Language Institute (HLI) and the data obtained through distributing a questionnaire to pre-intermediate students was analyzed analytically. Results show that all kinds of factors are hardly regarded separately. Yet, the linguistic factors are demonstrated to be dominant in learners' oral performance. Finally, certain treatments are presented depending on the data obtained and the most important was to implement an ungraded speaking test to lower speaking anxiety in oral exams. The research concludes with a brief summary, suggestions for further research, and some recommendations for the EEL context.
\end{abstract}

Index Terms - speaking anxiety, pre-intermediate level, oral performance, foreign language, willingness to communicate

\section{INTRODUCTION}

Starting from the early 1980s, the focal point of language teaching methods gradually shifted from focusing on mastering the structure to developing the communicative dimension which concentrates on knowing the language rather than knowing about the language (Brown, 2001). Consequently, the language components are no longer regarded in isolation from their actual use and that requires paying more attention to practicing the language i.e. speaking. This approach is referred to as 'Communicative Language Teaching' (CLT) which started to be applied in many EFL contexts due to its prime goal in developing learners' communicative competence as Richards \& Rodgers stated in 1986. They believe that learning any language is only possible through communication. However, applying this approach can form another problem because learners' weakness would be highly exposed through having many opportunities for speaking using the target language.

"Anxiety is one of the most negative psychological hinders for many EFL Learners" (Maouche, 2010, p. 8). It is clear that anxiety is a crucial point to consider in learning a foreign language especially due to its emotional, physical, and psychological impediments on learning and practicing the language. It also hampers learning the language because anxious learners seem to be less willing to communicate and the effects of anxiety are clear especially in the oral activities (Subaş1, 2010). Willingness to communicate (WTC) is associated with anxiety and the way learners perceive their competence in the sense that they might underestimate their abilities and thus, tend not to speak. Likewise, MacIntyre in 1995 detected a cyclical relation between anxiety, competence, and performance. Anxiety affects the cognitive domain and by that performance would be harmfully affected causing "negative self-evaluation and more selfdeprecating cognition which further impairs performance" (p. 92). By this process, learners would feel the same situation every time they use the target language.

The use of modern communicative language teaching approach, which focuses on learning the language through speaking, has increased in several countries and Syria is no exception. Many EFL institutes for teaching EFL started to implement the communicative approach as a method for teaching English as a foreign language. This has increased the demand to have solutions for the different sources of speaking anxiety that constitute barriers harmfully influencing EFL learners' willingness to communicate using the target language.

Research questions:

The study attempts to provide answers to the following questions:

1. What reasons are more probable to cause speaking anxiety to pre- intermediate EFL learners?

2. What are the suggestions that can alleviate different sources of anxiety?

Significance of the study:

Since speaking is said to be one of the most important skills reflecting the mastery of a foreign language in our modern world, this study tackles an essential realization and projection of the EFL learners' most important skill: Speaking, and the barriers behind its realization, namely, anxiety with all its aspects through focusing on the causes and effects hindering EFL learners' willingness to communicate and negatively affecting oral performance in the target language. 


\section{Literature review:}

Lindsay and Knight (2006) believe that "Speaking is a productive skill; it involves putting a message together, communicating the message, and interacting with other people" (p.57). Even though the focus of language teaching process shifted to using language for communicative purposes rather than mastering its structure as Cetinkaya suggests (2005), there are certain linguistic factors that might affect learners' course of conversation as Bach and Harnish (1979) think, and such factors could also affect learners' linguistic competence unconstructively.

Acquiring new vocabularies is considered to be a problem to a great number of EFL learners as they claim to have good thoughts but poor vocabulary to express them truly (Subaş1, 2010). Similarly, Tanveer in his research (2007) stresses the importance of remembering and retrieving words as EFL learners proved to become anxious when they do not have enough vocabs to express their ideas which might result in impeding fluency and thus causing speaking anxiety (SA). A good number of EFL Learners' desired goal is to speak with a native-like accent which means that speaking and pronunciation are strongly connected together in the EFL learners' mind (Derwing \& Munro, 2005). However, Brown in 2001 claimed that most FLE learners, especially adults, are less able to acquire a native-like accent. This suggests that not having the desired pronunciation or not knowing how to pronounce words correctly might affect learners' willingness to initiate talks using the language and a good example is presented in Subaş1's study when one participant claims: "I always make pronunciation errors while speaking in the target language and observe a humiliating manner on my classmates' faces; this makes me angry" (2010, p. 43). Furthermore, learning new grammar rules is regarded to be the second linguistic factor causing anxiety to EFL learners according to the results of Tanveer's study in 2007. EFL learners claim to be stressed as a result of being unsure most of the time of what tense to use in their speaking attempts. This gives clear evidence that grammar is strongly related to speaking the language (Tanveer, 2007; Irzeqat, 2010). Thus, having difficulties in acquiring new grammar rules, understanding them, and using those rules in speaking can form one major linguistic factor passively affecting EFL learners' eagerness to speak.

Increasing the competence of EFL learners has the purpose of communicating using the target language (McCroskey et al., 1985a), and speaking is a process that can hardly be seen taking place aside from speakers' psychological and social situations (Bach \& Harnish, 1979). So, there is a great interdependence between communication and the psychological readiness of learners (MacIntyre, 2003). Maouche (2010) says: "EFL students may generate negative expectations, harmful beliefs and perception that often affect their performance" (p.20). There are a number of misconceptions EFL learners might have in mind regarding certain domains in the language learning process. One mistaken belief some learners strongly believe in is that they must have a native-like accent in order to speak the language, and such an idea can damagingly affect their performance due to the possibility of lacking what they consider to be the core of learning the language (Maouche, 2010; Irzeqat, 2010). In the psychological domain, anxiety is considered by Kimura (2002) to be the opposite of the two terms 'high self-esteems' and 'willingness to take risks.' In addition, he hypothesizes that successful learners show high self-esteem and have less anxiety in oral communication. Correspondingly, low level of self-esteem means higher level of anxiety as many learners would claim in this case that they have no important ideas to present in conversations (McCroskey \& Richmond, 1990; Wilson, 2006).

Several social factors are considered by a number of researchers to cause speaking anxiety to EFL learners. The most reported anxiety provoking social factors are: The general classroom atmosphere (context), teachers' role in classroom concerning the rapport between them and learners, speaking activities presented to learners, error correction techniques, and ways of evaluating learner' oral performance. Another set of social factors are related to learners' fear of making mistakes and negative evaluation in speaking tests, in addition to the potential effect of age and gender differences on oral performance. "The use of communicative methodologies implies greater demands on learners to communicate and therefore higher likelihood of exposure to anxiety-inducing situations" (Cebreros, 2003, p.6), and this can be greatly noticed in the classroom context. Generally speaking, the context of foreign language learning gives EFL learners limited opportunities to practice using the language (Tanveer, 2007). That is why their communicative skills would not be fully developed which might result in experiencing the feeling of anxiety.

The problem of speaking anxiety has several effects on EFL learners' WTC, oral performance, and their marks in oral tests (Cutrone, 2009; Maouche, 2010; Riasati, 2011). Tóth (2011) deduces that learners used to remain silent even if they have something to say and they resort to using the first language instead of the target language with an attempt to save themselves from being in embarrassing situations in front of others. Similarly, Tanveer (2007) affirms that speaking anxiety affects EFL learners' oral attempts which results in having poor performance, less enthusiasm and willingness to speak. McCroskey \& Richmond (1990) believe that speaking anxiety affects learners' WTC level. Thus, learners with low WTC level are seen negatively by peer unlike the willing ones with high level of WTC who are more likely to enjoy the experience of learning the language.

The first step to overcome the problem of anxiety in the language learning process according to many researchers is to become aware of its existence, identify the factors, and recognize its manifestations (Cebreros, 2003; Tanveer, 2007). Some researchers acknowledge that teachers rarely do take serious steps to deal with speaking anxiety. Yet, they cannot be blamed entirely because learners can also participate in reducing their own anxiety through preparation and participation (Riasati, 2011). Tanveer's suggestions (2007) focus on two main categories causing speaking anxiety including the linguistic and the social ones. With regard to the linguistic factors, Tanveer presents one solution to the problem of having a native-like pronunciation which is to cease from making it a model to follow. This contradicts 
Irzeqat's (2010) suggested way of dealing with anxiety regarding this point as she believes in the importance of having confidence in pronunciation. As a result, she recommends that teachers can speak with a native-like example of pronunciation to be role models to follow by learners.

\section{METHODOLOGY}

\section{Course description and participants:}

The current study was conducted at The Higher Language Institute (HLI) that gives people the chance to enroll in English courses from foundation till advanced levels basically depending on the results of a placement test which does not test the speaking skills. The subjects of the study are 17 pre- intermediate EFL learners taking courses at HLI. Each course at The Higher Language Institute consists of 20 sessions divided into 40 hours, two hours for each session and two exams; one takes place in the middle of the course entitled midterm exam containing four sections: listening, reading, writing, and grammar which means that speaking has no part whatsoever in the midterm exam. The other one is the final exam which includes the same sections of the midterm one, in addition to a speaking test called 'interview.' So, all the four skills are tested twice in the midterm and in the final exams except the skill of speaking which is tested only one time in the final exam and is given 10 marks out of 100 in the pre-intermediate level final score.

The instrument:

Data from real life situations of using the English language is collected, described, and analyzed. The method implemented in this study is analytical in order to investigate speaking anxiety factors, effects on EFL learners WTC, and learners' actual oral performance for communicative purposes. The questionnaire was given to learners after the completion of the course with the aim of investigating the causes leading to speaking anxiety especially the linguistic and the social ones. The items included in the questionnaire followed the closed form instead of the open-ended one as the former proves to be easily analyzed (Wilson, 2006). In addition, the presented choices in the questionnaire were: Strongly agree (SA) - Agree (A) - Neither agree nor disagree (N) - Disagree (D) - Strongly disagree (SD). These variables are included with an attempt to regard different levels of approving or disapproving, but in analyzing the results, and to make them easy to digest and categorize, there will be three main retorts incorporating: agree, neither agree nor disagree, and disagree. The items of the questionnaire were mostly adapted from Foreign Language Classroom Anxiety Scale (FLCAS) by Horwitz, Horwitz \& Cope 1986 which is described as being valid and reliable by Hashimoto (2002).

Data analysis:

Data collection occurred over a period of two months as the courses, in the time which the study was implemented, used to have 3 sessions per week. That is why the 20 sessions lasted for nearly two successive months.

\section{RESULTS AND ANALYSIS}

This section presents answers to the two questions raised in this study. The answers are based on analyzing data collected from the questionnaire which was distributed to students at the end of the course.

What reasons are more probable to cause speaking anxiety to pre- intermediate EFL learners? 
TABLE 1

PRE-INTERMEDIATE QUESTIONNAIRE RESULTS ON SA FACTORS

\begin{tabular}{|c|c|c|c|}
\hline Factors & $\begin{array}{c}\text { Agreement } \\
\text { Strongly agree (SA) } \backslash \text { Agree (A) }\end{array}$ & Neutral & $\begin{array}{c}\text { Disagreement } \\
\text { Strongly disagree (SD) Disagree (D) }\end{array}$ \\
\hline 1. anxiety in general & $\begin{array}{l}\mathbf{1 7 . 6 4 \%} \text { [SA: } 5.88(1)-\mathbf{A}: 11.76 \\
(2)]\end{array}$ & $0 \%$ & 82.35\% [D:35. $29(6)-$ SD: $47.05(8)]$ \\
\hline \multicolumn{4}{|l|}{ Linguistic Factors: Items from $2 \rightarrow 9$} \\
\hline 2. language class moves too quickly & $\mathbf{5 2 . 9 4 \%}$ \% [SA:5.88 (1)- A:47.05 (8)] & $\begin{array}{l}23.52 \% \\
\text { (4) }\end{array}$ & 23.52\% [D: 23.52 (4) - SD: 0] \\
\hline $\begin{array}{l}\text { 3. be upset upon not understanding } \\
\text { everything in class }\end{array}$ & $\begin{array}{l}\text { 64.70 \% [SA: } 11.76(2)-\mathbf{A :} 52.94 \\
(9)]\end{array}$ & $0 \%$ & $35.29 \%[D: 23.52(4)-$ SD: $11.76(2)]$ \\
\hline 4. overwhelmed by grammar rules & $\begin{array}{l}\mathbf{5 2 . 9 4} \% \text { [SA: } 23.52(4)-\mathbf{A}: 29.41 \\
(5)]\end{array}$ & $5.88 \%(1)$ & 41.17\% [D: 35.29 (6)- SD: 5.88 (1) \\
\hline $\begin{array}{l}\text { 5. unable to express ideas due to lack of } \\
\text { knowledge in the use of the right tense }\end{array}$ & $\begin{array}{l}\mathbf{8 8 . 2 3} \% \text { [SA: } 29.41(5)-\mathbf{A :} 58 . \\
82 \\
(10)]\end{array}$ & $5.88 \%$ & $\mathbf{5 . 8 8 \%}[$ D: $5.88(1)-$ SD: $0 \%]$ \\
\hline 6. good ideas but poor vocabs & $\begin{array}{l}\mathbf{5 2 . 9 4} \% \text { [SA: } 23.52 \text { (4)- A: } 29.41 \\
(5)]\end{array}$ & $\begin{array}{c}11.76 \% \\
(2)\end{array}$ & $35.29 \%$ [D:35. 29 (6)- SD: 0] \\
\hline $\begin{array}{l}\text { 7. unable to remember the wide range of } \\
\text { vocabs I have }\end{array}$ & $\begin{array}{l}\text { 41.17 \% [SA: } 17.64(3)-\mathbf{A}: 23.52 \\
(4)]\end{array}$ & $\begin{array}{c}23.52 \% \\
(4)\end{array}$ & $35.29 \%$ [D: $35.29(6)-$ SD: 0$]$ \\
\hline $\begin{array}{l}\text { 8. knowing many vocabs but unsure what } \\
\text { to use }\end{array}$ & 64.70 \% [SA: 0- A: $64.70(11)]$ & $\begin{array}{l}5.88 \% \\
(1)\end{array}$ & 29.41\% [D: 29.41 (5) - SD: 0] \\
\hline 9. I have excellent pronunciation & $\begin{array}{l}\mathbf{5 2 . 9 4} \% \text { [SA: } 5.88(1)-\mathbf{A :} 47.05 \\
(8)]\end{array}$ & $\begin{array}{l}5.88 \% \\
(1)\end{array}$ & 41.17\% [D: 41.17\% (7) - SD: 0] \\
\hline \multicolumn{4}{|c|}{ Psychological Factors: Items from $10 \rightarrow 18$} \\
\hline $\begin{array}{l}\text { 10. having native-like accent is more } \\
\text { important than speaking accurately }\end{array}$ & $\begin{array}{l}\text { 47.05 \% [SA: } 11.76(2)-\mathbf{A}: 35.29 \\
(6)]\end{array}$ & $\begin{array}{l}5.88 \% \\
(1)\end{array}$ & 47.05\% [D: 35.29 (6)-SD: $11.76(2)]$ \\
\hline $\begin{array}{l}\text { 11. able to express myself successfully } \\
\text { while speaking English. }\end{array}$ & $\begin{array}{l}\mathbf{4 7 . 0 5} \% \text { [SA: } 11.76 \text { (2)- A: } 35.29 \\
(6)]\end{array}$ & $\begin{array}{l}17.64 \% \\
\text { (3) }\end{array}$ & $35.29 \%$ [D: $35.29 \%$ (6) - SD: 0] \\
\hline $\begin{array}{l}\text { 12. I'm a very good English language } \\
\text { learner }\end{array}$ & $\begin{array}{l}35.29 \% \text { [SA: } 5.88(1)-\mathbf{A}: 29.41 \\
(5)]\end{array}$ & $\begin{array}{c}23.52 \% \\
(4)\end{array}$ & 41.17\% [D: $35.29(6)$ - SD: 5.88 (1)] \\
\hline $\begin{array}{l}\text { 13. speaking the language is a gift that not } \\
\text { everyone has }\end{array}$ & $\begin{array}{l}\mathbf{5 8 . 8 2} \% \text { [SA: } 23.52(4)-\mathbf{A}: 35.29 \\
(6)]\end{array}$ & $\begin{array}{c}5.88 \% \\
(1)\end{array}$ & 35.29\% [D: 29.41 (5) - SD: 5.88 (1)] \\
\hline $\begin{array}{l}\text { 14. other learners speak English better than } \\
\text { me. }\end{array}$ & $\begin{array}{l}29.41 \% \text { [SA: } 11.76(2)-\mathbf{A}: 17.64 \\
(3)]\end{array}$ & $\begin{array}{c}23.52 \% \\
(4)\end{array}$ & 47.05\% [D: 29.41 (5) - SD: 17.64 (3)] \\
\hline $\begin{array}{l}\text { 15. I became very anxious about speaking } \\
\text { English in front of all learners }\end{array}$ & $\begin{array}{l}35.29 \% \text { [SA: } 23.52(4)-\mathbf{A}: 11.76 \\
(2)]\end{array}$ & $\begin{array}{c}5.88 \% \\
(1)\end{array}$ & 58.82\% [D: 41.17 (7) - SD: 17.64 (3)] \\
\hline $\begin{array}{l}\text { 16. My personality affects my oral } \\
\text { performance in the classroom. } \\
\text { classroom. }\end{array}$ & $\begin{array}{l}70.58 \% \text { [SA: } 23.52(4)-\mathbf{A}: 47.05 \\
(8)]\end{array}$ & $\begin{array}{l}23.52 \% \\
(4)\end{array}$ & $\mathbf{5 . 8 8 \%}[\mathrm{D}: 0-$ SD: $5.88(1)]$ \\
\hline $\begin{array}{l}\text { 17. become too nervous when the teacher } \\
\text { asks me to speak something I did not } \\
\text { prepare in advance. }\end{array}$ & $\begin{array}{l}\mathbf{5 2 . 9 4} \% \text { [SA: } 11.76(2)-\mathbf{A}: 41.17 \\
(7)]\end{array}$ & $\begin{array}{l}5.88 \% \\
(1)\end{array}$ & 41.17\% [D: 23.52 (4) - SD: 17.64 (3)] \\
\hline $\begin{array}{l}\text { 18. It embarrasses me to volunteer answers } \\
\text { in my English course }\end{array}$ & $35.29 \%[$ SA: $0-\mathbf{A :} 35.29(6)]$ & $\mathbf{0}$ & 64. 70\% [D: $58.82(10)-$ SD: $5.88(1)]$ \\
\hline \multicolumn{4}{|l|}{ Social Factors: Items from $19 \rightarrow 25$} \\
\hline $\begin{array}{l}\text { 19. The classroom atmosphere is very } \\
\text { positive. }\end{array}$ & $\begin{array}{l}\mathbf{8 2 . 3 5} \% \text { [SA: } 17.64(3)-\mathbf{A :} 64.70 \\
(11)]\end{array}$ & $\begin{array}{c}17.64 \% \\
(3)\end{array}$ & 0 \\
\hline $\begin{array}{l}\text { 20. We are not given the appropriate } \\
\text { opportunities to speak in the class. }\end{array}$ & $\begin{array}{l}\begin{array}{l}35.29 \% \\
(5)]\end{array} \\
\end{array}$ & $\begin{array}{c}11.76 \% \\
(2)\end{array}$ & 52.94\% [D: 41.17 (7)- SD: $11.76(2)]$ \\
\hline 21. I'm afraid of making mistakes. & $\begin{array}{l}\text { 17.64 \% [SA: } 11.76(2)-\mathbf{A}: 5.88 \\
(1)]\end{array}$ & $5.88 \quad(1)$ & 76.47\% [D: $47.05(8)-$ SD: $29.41(5)]$ \\
\hline $\begin{array}{l}\text { 22. The way the teacher corrects my oral } \\
\text { mistakes makes me lose face. }\end{array}$ & $5.88 \%$ [SA: $0-\mathbf{A}: 5.88(1)]$ & $\begin{array}{l}11.76 \% \\
(2)\end{array}$ & $82.35 \%$ [D: 52.94 (9) - SD: 29.41 (5)] \\
\hline $\begin{array}{l}\text { 23. I'm relaxed before and during the } \\
\text { speaking tests. }\end{array}$ & $29.41 \%$ [SA: 0 - A: 29.41 (5)] & $\begin{array}{l}17.64 \% \\
(3)\end{array}$ & $52.94 \%$ [D: $35.29(6)$ - SD: $17.64(3)]$ \\
\hline $\begin{array}{l}\text { 24. The more I prepare for the speaking } \\
\text { tests, the more I became anxious about it. }\end{array}$ & $\begin{array}{l}\text { 58.82 \% [SA: } 17.64(3)-\text { A: } 41.17 \\
(7)]\end{array}$ & $\begin{array}{c}11.76 \% \\
(2)\end{array}$ & 29.41\% [D: 29.41(5) - SD: 0] \\
\hline $\begin{array}{l}\text { 25. My previous experience in learning the } \\
\text { language affects my current oral } \\
\text { performance in classroom. }\end{array}$ & $\begin{array}{l}11.76 \% \text { [SA: } 5.88(1)-\mathrm{A}: 5.88 \\
(1)]\end{array}$ & $\begin{array}{l}17.64 \% \\
\text { (3) }\end{array}$ & $70.58 \%$ [D: 52.94 (9) - SD: 17.64 (3)] \\
\hline
\end{tabular}

The results show that all three categories of factors contribute to causing speaking anxiety to pre-intermediate learners. However, linguistic factors proved to be the most anxiety-promoting type of factors especially since learners, who belong to this level, are still relatively at an early stage of learning and acquiring the language. This is also found in Cetinkaya's study (2005) deducing that grammar and vocabulary play a very negative role affecting learners' WTC and oral production. Depending on Cetinkaya's deduction, learners suffer greatly when attempting to speak using the target language as their knowledge about the linguistic elements is still comparatively poor.

Psychological factors are ranked second as some items provide evidence of their ability to affect WTC and speaking attempts. Most of the reported psychological factors by learners are related to misconception regarding the language learning process since a number of them (more than $47 \%$ ) consider speaking with a native-like accent to be more 
important than speaking accurately, in addition to the fact that nearly 59\% of learners suppose that speaking the target language is a gift that is not granted to all people. Furthermore, some learners believe in the say that 'they are what they speak' which can influence their ability to truly rank their speaking capabilities. Previous studies such as Ohata (2005); Cutrone (2009) and Ramírez (2010) gave more weight to the psychological causes as well as the social ones. Some focused heavily on the psychological factors thinking that these kinds of causes have the greatest harmful impact that affects learners' speaking attempts. However, in this study, the psychological kind of factors has a less negative effect than the linguistic one as pre-intermediate learners are still not fully aware of the problem of anxiety and its effects on their speaking endeavors.

Contrary to previous studies, the social factors proved to exert a minimal negative impact on pre-intermediate learners' speaking attempts. Only the fear of the speaking test, which can also be a psychological factor since all three categories are related to some extent, proved to have a negative impact on speaking endeavors during oral exams. This contradicts Tanveer's presuppositions (2007) that the social factors are more important to focus on than other types of factors.

\section{What are some possible ways to address these problems?}

A number of alleviations were presented in the related literature; however, in this study treatments and alleviations are set taking into account the special context in which the study is conducted. Moreover, remedies to be suggested must go hand in hand with the sources of speaking anxiety. In other words, they should be reflected on the certain factors causing speaking anxiety to EFL learners of pre-intermediate level under investigation in the milieu of HLI.

The prime aim of answering this question is to suggest alleviations to the problem of speaking anxiety parallel to the types of factors learners proved to be more anxious at. Therefore, this study has proposed two types of possible ways that can lessen the level of speaking anxiety. The two suggested kinds of treatment have been divided into two subsections. The first one provides a set of ideas suggested by learners, in addition to the study's contributions based on the results gathered in order to deal with speaking anxiety in the classroom. The majority of the suggested ideas is to deal with the linguistic type of factors, but includes other social and psychological ideas since the problem of speaking anxiety cannot be regarded in isolation from other types of factors. Depending on the data obtained previously from learners, a number of possible remedies are presented in the following table.

TABLE 2

POSSIBLE REMEDIES To THE PROBLEM OF SPEAKING ANXIETY

\begin{tabular}{|l|l|}
\hline $\mathbf{1}$ & Discussing the problem with learners of all levels \\
\hline $\mathbf{2}$ & Pinpointing the negative influence originated from speaking anxiety \\
\hline $\mathbf{3}$ & Teachers' role in the classroom \\
\hline $\mathbf{4}$ & Enhancing the skill of speaking through presenting more speaking chances in classrooms \\
\hline $\mathbf{4}$ & Choosing interesting topics for discussion \\
\hline $\mathbf{5}$ & Putting objectives for speaking activities \\
\hline $\mathbf{6}$ & Implementing the use of grammar in speaking \\
\hline $\mathbf{7}$ & Taking into account learners' number in every class \\
\hline
\end{tabular}

In the second one, the study suggests adding a second 'interview' in the midterm exam which includes no speaking test. The purpose is to lessen the feeling of anxiety which may result from the fear of evaluation and getting low marks. This idea depended heavily on learners' positive reaction toward inserting this ungraded speaking test that might decrease the negative feeling of SA.

\section{DiSCUSSION AND CONCLUSION}

Speaking is a multifaceted construct and it is considered to be the most important skill to master in learning the language. Learners regard speaking to be the sign of being knowledgeable about the language. This belief has increased since English is the language of communication internationally (Nazara, 2011). Many features play a vital role in making learners willing to speak; some of these features are learners' psychology and the situation in which they are going to communicate with others (MacIntyre, 2007). Different types of linguistic, psychological, and social factors can negatively affect learners' WTC and speaking attempts. Moreover, Tanveer declares that "students' feeling of stress, anxiety or nervousness may impede their language learning and performance abilities" (2007, p.1). Depending on data analysis, it has been deduced that all factors contribute in making learners of both levels feel anxious while speaking especially the linguistic ones. This contradicts other studies which showed great effects exerted by the social factors (Ohata, 2005).

To conclude, the first step to cope with the problem of speaking anxiety is to identify the factors and recognize the manifestations (Tanveer, 2007). That is why discussing this problem with learners can be highly beneficial assuming that their point of view can play a major role in suggesting specific remedies that may reflect the real type of factors that cause them to feel more anxious while speaking. Another point to consider is not to underestimate discussing the issue of speaking anxiety with the more advanced level, but rather to provide possible treatments to this problem having the same enthusiasm with all different levels. 


\section{REFERENCES}

[1] Bach, K., \& Harnish, M.R (1979). Linguistic communication and speech acts. The MIT Press: Massachusetts.

[2] Brown, H, D. (2001). Teaching by principle: an interactive approach to language pedagogy, second edition. San Francisco: San Francisco state University.

[3] Cebreros, A. M. (2003). Measuring language anxiety perceived by Spanish university students of English. Retrieved Nov 20, 2019, from www.publications.ub.edu/revistes/bells12/PDF/art11.pdf.

[4] Cetinkaya, Y. B. (2005). Turkish college student's willingness to communicate in English as a foreign language. (Doctorial dissertation). Retrieved June 12, 2018, from http://etd.ohiolink.edu.

[5] Cutrone, P. (2009). Overcoming Japanese EFL Learners' Fear of Speaking. University of Reading: Language studies working papers, (1), 55-63. Retrieved June 12, 2018, from www.reading.ac.uk/internal/appling/Cutrone.pdf.

[6] Derwing, T. M., \& Munro. M. J. (2005). Second language accent and pronunciation teaching: A Research-Based Approach. TESOL Quarterly, 39 (3), 379-397

[7] Hashimoto, Y. (2002). Motivation and willingness to communicate as predictors of L2 use: The Japanese ESL context. Second Language Studies, 20(2), 29-70.

[8] Horwitz, E.K., M.B. Horwitz and J. Cope. (1986). Foreign Language Classroom Anxiety. The Modern Language Journal 70: 125-132.

[9] Irzeqat, N. S. (2010). The Effect of anxiety on the oral performance of Palestinian students of English from the perspectives of teachers and students. (MA thesis). Retrieved June 12, 2018, from home.birzeit.edu/librarya.

[10] Kimura, M. (2002). Affective factors of Japanese EFL learners at junior college in the oral communication tasks. Retrieved Jan 15, 2020, from ses-online.jp.

[11] Lindsay, C. \& Knight, P. (2006). Learning and teaching English. New York: Oxford University Press.

[12] MacIntyre, P. D. (1995). How does anxiety affect second language learning? A reply to Sparks and Ganschow. The Modern Language Journal, 79 (1), 90-99.

[13] MacIntyre, P. D. (2007). Willingness to communicate in a second language: Individual decision making in a social context. Presented at UOC conference in Barcelona. Retrieved from www.uoc.edu/Barcelona_paper_for_UOC_Conference.pdf.

[14] Maouche, M. M. (2010). Reducing Anxiety and Raising Engagement in Oral Classroom Settings through Better Teachers' Sociability. (MA thesis). Retrieved Nov 20, 2019, from http://80.246.8.22/theses/anglais/MAO1114.pdf.

[15] McCroskey, J. C., Gudykunst, W. B., and Nishida, T. (1985). Communication apprehension among Japanese students in native and second language. Communication Research Reports, 2 (1), 11-15.

[16] McCroskey, J. C., \& Richmond, V. P. (1990). Willingness to communicate: a cognitive view. A Special issue of the Joumal of Social Behavior and Personality, 5 (2), 21-37.

[17] Nazara, S. (2011). Students' perception on EFL speaking skill development. JET, 1 (1), 28 - 43.

[18] Ohata, K. (2005). Language anxiety from the teachers' perspective: Interviews with seven experienced ESLIEFL teachers. Journal of Language and Learning, 3 (1), 133-155.

[19] Ramírez, V. A. (2010). Students' perception about the development of their oral skills in English as a foreign language: teacher training program. (MA thesis). Retrieved Jan 20, 2017, from repositorio.utp.edu.com.

[20] Riasati, M. J. (2011). Language learning anxiety from EFL learners' perspective. Middle- East Journal of Scientific Research, 7 (6), 907-914

[21] Richards, J.C., \& Rodgers, T. (1986). Approaches and Methods in Language Teaching: A Description and Analysis. Cambridge University Press, Cambridge.

[22] Subaş1, G. (2010). What are the main sources of Turkish EFL students' anxiety in oral practice? Turkish Online Journal of Qualitative Inquiry, 1 (2), 29-49.

[23] Tanveer, M. (2007). Investigation of the factors that cause language anxiety for ESL/EFL learners in learning speaking skills and the influence it casts on communication in the target language. (MA thesis). Retrieved Dec 7, 2018, from http://www.asianefl- journal.com/thesis_M_Tanveer.pdf.

[24] Tóth, Z. (2011). Foreign language anxiety and advanced level learners: An interview study. WoPaLP, 5. Retrieved Aug 12, 2020, from langped.elte.hu.

[25] Wilson, J. S. (2006). Anxiety in learning English as a foreign language: Its association with student variables, with overall proficiency, and with performance on an oral test. (Doctorial dissertation).Retrieved Oct 3, 2020, from www.ccsenet.org/journal/index.php/ijel/article/.

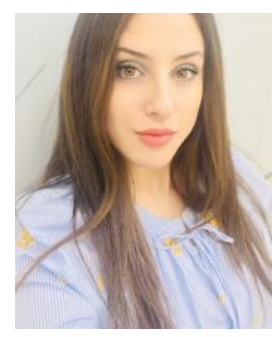

Sarah Al-Mukdad, born in Damascus, Syria, August, 1988. Has a BA in English language and literature at Damascus University (2010) and Got MA in teaching English as a foreign language TEFL at Damascus University (2015).

She has worked for The Higher Language Institute HLI, Damascus, Syria (2013- 2019). She is teaching English at Damascus University (2011- present) and Syrian Virtual University (2019- present) and Arab International University, Damascus, Syria (2014-present). 